\title{
Do Antimetabolites Interfere with the Glycosylation of Cellular Glycoconjugates?
}

\author{
G.J. Peters, H.M. Pinedo, W. Ferwerda, T.W. de Graaf and W. van Dijk
}

\begin{abstract}
INTRODUCTION
ANTIMETABolites are frequently used for the treatment of various neoplastic diseases, including solid tumors and leukemias [1], but the use of these compounds is limited by the occurrence of myeloid and gastrointestinal toxicity. For most of these drugs the mechanism of action has been investigated extensively in vitro and in vivo [1-5]. These studies, in general, point to interference in purine or pyrimidine biosynthesis ( $c f$. Table 1) leading to inhibition of DNA and/or RNA synthesis in dividing cells. Additional mechanisms, however, might be responsible for the cytotoxic effects on non-dividing cells, i.e. the majority of normal cells and tumor cells which are in resting phase.
\end{abstract}

Several antimetabolites interfere with the manufacture of nucleotides (UTP, GTP and CTP) that are substrates for the manufacture of nucleotide sugars. Since nucleotide sugars are the precursors for the biosynthesis of glycoconjugates ( $c f$. Fig. 1), the glycosylation of both secreted and membrane-associated glycoconjugates might be affected in the presence of antimetabolites. The sugar chains extending from the cell surface are important determinants of the phenotype of cells [6] and have been implicated in a variety of cell surface interactions [6-10].

Characteristic changes in cell surface oligosaccharides accompany normal and malignant development and hematopoietic differentiation [11-22]. Thus, for a variety of malignant cells a characteristic increase in molecular weight, caused by changes in branching [11-17] and/or increased amount of sialic acid [11, 12, 16-18], has been observed for cell surface oligosaccharide structures in comparison with those from non-malignant cells. The invasive capacity of cells $[17,19,20]$ and the loss of binding of malignant cells to the substratum $[12,21]$ is related positively to the observed increase in molecular weight. In the last decade the evidence is compelling that the variations in oligosaccharide structures observed coincide with changes in activities of specific glycosyltransferases [e.g. 14, 21, 23-26], indicating the importance of these enzymes in the regulation of the glycosylation process.

The general occurrence of characteristic changes in glycoconjugates in relation to malignancy and differentiation gives sup-

Correspondence to G.J. Peters.

G.J. Peters and H.M. Pinedo are at the Department of Oncology, Free University Hospital, P.O. Box 7057, Amsterdam and W. Ferwerda, T.W. de Graaf and W. van Dijk are at the Department of Medical Chemistry, Faculty of Medicine, Vrije Universiteit, P.O. Box 7161, Amsterdam, The Netherlands. Dr G.J. Peters is the recipient of a senior research fellowship of the Royal Netherlands Academy of Sciences.

Abbreviations: AraC, arabinofuranosylcytosine; $5 \mathrm{FU}, 5$-fluorouracil; FUR, 5-fluorouridine; FUdR, 5-fluoro-2'-deoxyuridine; MTX, methotrexate; PALA, $N$-(phosphonacetyl)-L-aspartate. port to the idea that the cell surface oligosaccharide structures are functionally involved in the accompanying change in phenotypic properties. Therefore, antimetabolite-induced alterations in glycosylation (e.g. extent of glycosylation, degree of branching or sialylation) might affect cell function of both normal and cancer cells.

In this article we review the effects of antimetabolites on different aspects of the glycosylation process in normal and tumor cells described thus far.

\section{INVOLVEMENT OF NUCLEOTIDE SUGARS IN THE REGULATION OF THE GLYCOSYLATION PROCESS}

A wide variety of oligosaccharide structures are present on cellmembrane glycoproteins and glycolipids. Their biosynthesis requires a non-template post-translational process in the lumen of the endoplasmatic reticulum and/or the Golgi complex. A large number of glycosyltransferases are involved in the regulation of this process [27-30]. These enzymes transfer the sugar residues from the nucleotide sugar to the growing carbohydrate chain. Nucleotide sugars are translocated from the cytosol into the Golgi vesicles via specific transporters, in exchange with the corresponding nucleoside monophosphate which are co-products of the transfer reactions (for review see ref. [31]). The glycosyltransferases are not only specific for the nucleotide sugar but also for the acceptor to be glycosylated, the anomeric configuration and the linkage type in which the sugar is attached [28]. Various reports demonstrate direct or indirect evidence that interference in the metabolism of nucleotide sugars or their translocation across the Golgi membrane result in structural changes in the oligosaccharide chains expressed on the cell surface. Thus, incubation of cells with galactosamine $\left(\mathrm{GalNH}_{2}\right)$ or glucosamine $\left(\mathrm{GlcNH}_{2}\right)$ strongly affected the cellular concentrations of uridine nucleotide sugars, with a concomitant inhibition of aberrant glycosylation of glycoproteins [32-35]. Furthermore, a defective translocation of CMP-sialic acid in the Chinese hamster ovary cell line Lec2 corresponded with a strong decrease in extent of sialylation of galactose or galactosamine residues on cell surface glycoproteins and glycolipids, in comparison to wild-type cells $[31,36]$. In another mutant, Lec8, the translocation of UDP-galactose was defective, resulting in a $80-90 \%$ reduction in both galactose and sialic acid residues in comparison to wild-type cells $[31,36]$.

\section{ANTIMETABOLITES AND GLYCOSYLATION}

Antimetabolites can interfere in three ways with nucleotide sugar metabolism. Firstly, the antimetabolite itself can be converted into a nucleotide sugar analog; secondly, the antimetabolite can deplete the levels of normal nucleotides leading to a depletion of nucleotide sugars; and thirdly, the concentration 
Table 1. Summary of known mechanisms of several antimetabolites

\begin{tabular}{|c|c|c|c|}
\hline Antimetabolite & $\begin{array}{l}\text { Active } \\
\text { intermediate }\end{array}$ & $\begin{array}{l}\text { Target } \\
\text { enzyme }\end{array}$ & $\begin{array}{l}\text { Postulated effect leading } \\
\text { to cell kill }\end{array}$ \\
\hline MTX & $\begin{array}{l}\text { MTX }+ \\
\text { polyglutamates }\end{array}$ & DHFR & $\begin{array}{l}\text { depletion of TTP } \\
\text { inhibition purine de novo }\end{array}$ \\
\hline $\begin{array}{l}6 \mathrm{MP} ; 6 \mathrm{MMPR} \\
6 \mathrm{TG}\end{array}$ & $\begin{array}{l}\text { 6-thio-IMP } \\
\text { 6-thio-GMP } \\
\text { 6-thio-GMP }\end{array}$ & & $\begin{array}{l}\text { inhibition purine de novo } \\
\text { incorporation nucleic acids } \\
\text { incorporation nucleic acids }\end{array}$ \\
\hline $\begin{array}{l}\text { Tiazofurin } \\
\text { Mycophenolic } \\
\text { acid }\end{array}$ & TAD & $\begin{array}{l}\text { IMP-DH } \\
\text { IMP-DH }\end{array}$ & $\begin{array}{l}\text { depletion GTP } \\
\text { depletion GTP }\end{array}$ \\
\hline AraC & Ara-CTP & DNA polymerase & $\begin{array}{l}\text { incorporation DNA } \\
\text { depletion dCTP }\end{array}$ \\
\hline PALA & & ATC & depletion UTP + CTP \\
\hline $\begin{array}{l}\text { Pyrazofurin } \\
\text { 6-Azauridine }\end{array}$ & $\begin{array}{l}\text { monophosphate } \\
\text { aza-UMP }\end{array}$ & $\begin{array}{l}\text { OPRT } \\
\text { OPRT }\end{array}$ & $\begin{array}{l}\text { depletion UTP + CTP } \\
\text { depletion UTP + CTP }\end{array}$ \\
\hline Acivicin & & $\begin{array}{l}\text { CPS-II } \\
\text { CTPsynthetase } \\
6 \mathrm{MP} \text { synthetase } \\
\text { purine de novo }\end{array}$ & $\begin{array}{l}\text { depletion purine }+ \\
\text { pyrimidine nucleotides }\end{array}$ \\
\hline $5 \mathrm{FU}$ & $\begin{array}{l}\text { FdUMP } \\
\text { FUTP }\end{array}$ & $\begin{array}{l}\text { thymidylate } \\
\text { synthase }\end{array}$ & $\begin{array}{l}\text { depletion TTP } \\
\text { incorporation into RNA }\end{array}$ \\
\hline Hydroxyurea & & $\begin{array}{l}\text { ribonucleotide } \\
\text { reductase }\end{array}$ & depletion deoxyribonucleotides \\
\hline
\end{tabular}

The data are taken from refs. [1-5]. DHFR, dihydrofolate reductase; IMP-DH, IMP dehydrogenase; ATC, aspartate transcarbamylase; OPRT, orotate phosphoribosyltransferase; CPS II, carbamylphosphate synthetase II. TAD is the diphosphate of tiazofurin. 6MP, 6-mercaptopurine; 6MMPR, 6-methylmercaptopurine riboside; 6T6, 6-thioguanine; FdUMP, 5-fluoro-deoxyUMP; FUTP, 5-fluoro-UTP.

of nucleotide sugars can be enhanced directly or indirectly. All mechanisms may lead to an interaction with glycosylation of proteins, because the kinetics of glycosyltransferase reactions are dependent on the presence and local concentration of the corresponding nucleotide sugar [29]. The latter compounds can be divided into two classes on the basis of the type of nucleotide: (i) pyrimidine-derived nucleotide sugars, UDP-hexoses, UDP$N$-acetylhexosamines and CMP-sialic acid, and (ii) purinederived nucleotide sugars, GDP-mannose and GDP-fucose. Therefore, in this article the effects of pyrimidine and purine antimetabolites on nucleotide sugar formation will be treated separately. The reviewed effects of antimetabolites on glycosylation are summarized in Tables 2 and 3.

\section{A. Nucleotide sugar formation}

(i) Effects of pyrimidine antimetabolites. $5 \mathrm{FU}$ has been reported to interfere with the incorporation of sugars into glycoproteins in murine L1210 leukemia cells [37] and to disturb cellular wall mucocomplex synthesis in bacteria [38]. In the last decade the possible pathway of interference of $5 \mathrm{FU}$ in glycoconjugate metabolism has been studied in various cell systems such as L1210 [39], colon cancers [40], sarcoma 180 [41], melanoma cells [42], S49 cells [43-45], TA3 mammary tumor cells [46], hepatoma [47, 48] and isolated hepatocytes [48]. It appeared that substantial amounts of 5-fluoro-derivatives of UDP-hexoses and/or UDP-N-acetylhexosamines could be formed during incubation of the cells in the presence of FUR
$[48,49]$. Also with the deoxynucleoside substrate, FUdR, the synthesis of a deoxynucleotide sugar, FdUDP- $N$-acetylglucosamine, could be demonstrated [50].

Inhibitors of pyrimidine de novo synthesis, such as PALA $[45,47]$ and 6-azauridine [45-47] can cause a depletion of the UTP pool with a concomitant sharp decrease of the total uridine nucleotide sugar pool. Such conditions favor the synthesis of

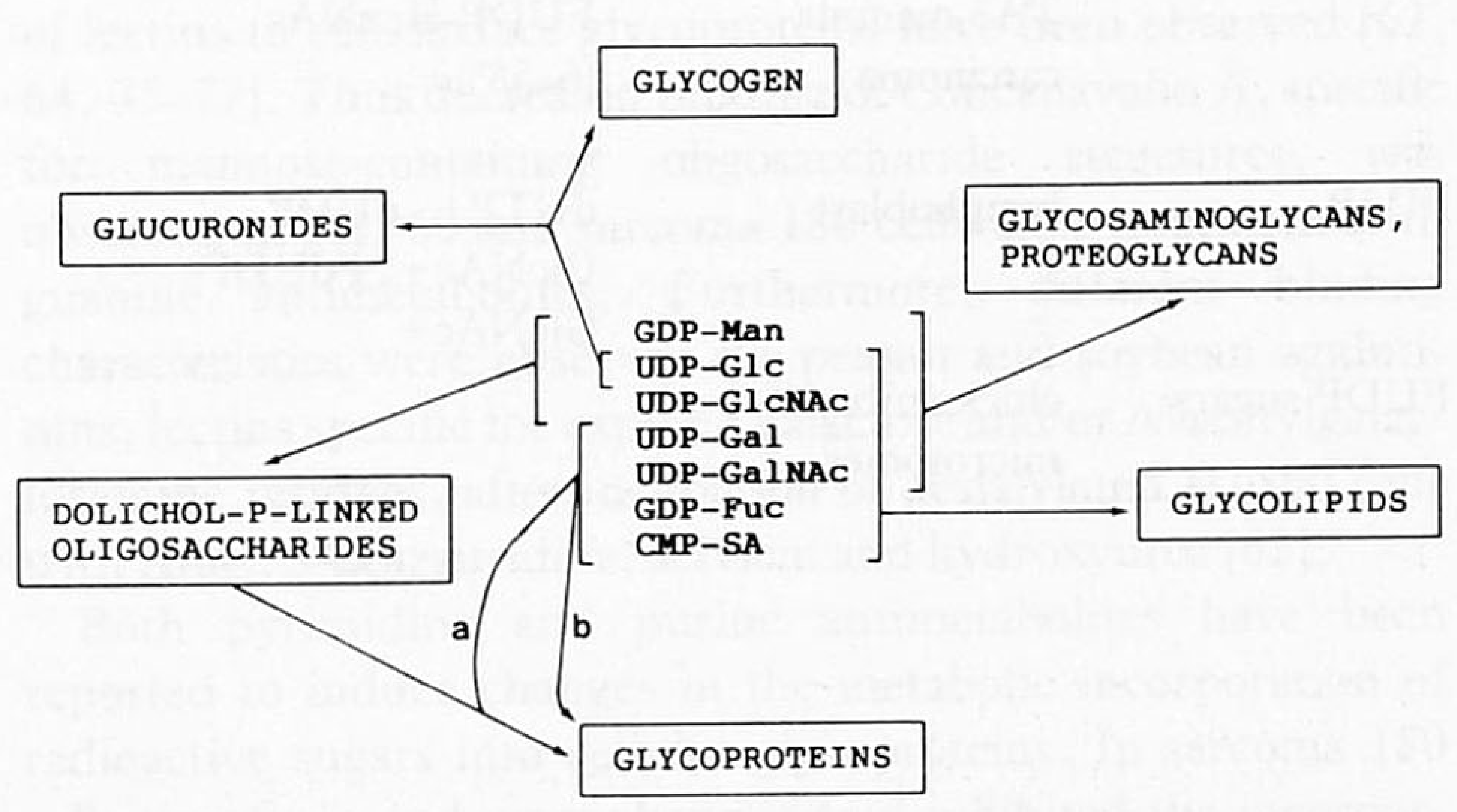

Fig. 1. Nucleotide-sugar-dependent reactions. The brackets embrace the group of nucleotide sugars that can participate in a certain metabolic route. Route a, asparagine-linked oligosaccharide structures; route $b$, serine- or threonine-linked oligosaccharide structures. Abbreviations used: Fuc, fucose; Gal, galactose; GalNAc, $\mathbf{N}$ acetylgalactosamine; Glc, glucose; GlcNAc, $\mathrm{N}$-acetylglucosamine; Man, mannose; SA, sialic acid. 
Table 2. Summary of literature on effects of fluoropyrimidines on glycosylation

\begin{tabular}{|c|c|c|c|c|c|c|}
\hline $\begin{array}{l}\text { Fluoro- } \\
\text { pyrimidine }\end{array}$ & Cell type & $\begin{array}{l}\text { Nucleotide } \\
\text { pools`}\end{array}$ & $\begin{array}{l}\text { Metabolic } \\
\text { incorporation }\end{array}$ & Miscellaneous & Combination & Ref. \\
\hline \multirow[t]{11}{*}{$5 \mathrm{FU}$} & L1210 leukemia & & $\begin{array}{l}{\left[{ }^{3} \mathrm{H}\right] \mathrm{Fuc} \downarrow} \\
{\left[{ }^{3} \mathrm{H}\right] \mathrm{GlcN} \uparrow}\end{array}$ & $\begin{array}{l}\text { cell surface } \\
\text { hydrophobicity } \uparrow\end{array}$ & & [37] \\
\hline & L1210 leukemia & & $\begin{array}{l}{\left[{ }^{3} \mathrm{H}\right] \mathrm{Fuc} \uparrow,} \\
{\left[{ }^{3} \mathrm{H}\right] \mathrm{GlcN} \uparrow,} \\
{\left[{ }^{3} \mathrm{H}\right] \mathrm{Gal} \uparrow} \\
{\left[{ }^{3} \mathrm{H}\right] \text { Man } \uparrow}\end{array}$ & & & [78] \\
\hline & E. coli & & & $\begin{array}{l}\text { accumulation } \\
\text { precursors cell wall } \\
\text { mucocomplex }\end{array}$ & & [38] \\
\hline & L1210 leukemia & FUDP-sugars (25\%) & & & & [39] \\
\hline & sarcoma 180 & FUDP-sugars (16\%) & & & $\begin{array}{l}\text { guanosine doubles } \\
\text { effect }\end{array}$ & [41] \\
\hline & $\begin{array}{l}\text { colon tumor } \\
\text { colon } \\
\text { spleen }\end{array}$ & $\begin{array}{l}\text { FUDP-Glc }+ \\
\text { FUDP-Glc- } \\
\text { FUDP-Glc }+\end{array}$ & & & & [40] \\
\hline & S49 lymphoma & FUDP-sugars & & & $\begin{array}{l}\text { uridine doubles } \\
\text { effect }\end{array}$ & [43] \\
\hline & melanoma & FUDP-sugars (6-30\%) & & & $\begin{array}{l}\text { PALA no } \\
\text { significant effect }\end{array}$ & [42] \\
\hline & ovarian tumor & & & galactosyltransferase $\downarrow$ & & [70] \\
\hline & $\begin{array}{l}\text { TA3 mamma } \\
\text { carcinoma }\end{array}$ & FUDP-HexNAc+ & & & $\begin{array}{l}\text { percentage dependent } \\
\text { on addition of GlcN } \\
\text { and/or 6-azauridine }\end{array}$ & [46] \\
\hline & rat hepatocytes & $\begin{array}{l}\text { FUDP-Hex }+, \text { FUDP- } \\
\text { HexNAc }+\end{array}$ & & & $\begin{array}{l}\text { thymine increases } \\
\text { effect } 2-6 \text { times }\end{array}$ & [48] \\
\hline , & H35 hepatoma & $\begin{array}{l}\text { FUDP-Hex }+, \text { FUDP- } \\
\text { HexNAc }+\end{array}$ & & & & [48] \\
\hline FUR & S49 lymphoma & $\begin{array}{l}\text { FUDP-GlcNAc+, } \\
\text { FUDP-GalNAc+ }\end{array}$ & & & & [44] \\
\hline & Morris hepatoma & $\begin{array}{l}\text { UDP-Glc } \downarrow \text {, FUDP- } \\
\text { Hex }+, \text { FUDP- } \\
\text { HexNAc+ }\end{array}$ & & & $\begin{array}{l}\text { in presence of GalN } \\
\text { and 6-azauridine or } \\
\text { PALA }\end{array}$ & [47] \\
\hline & AS-30D hepatoma & $\begin{array}{l}\text { FUDP-Hex (38\%), } \\
\text { FUDP-HexNAc }(16 \%)\end{array}$ & & & $\begin{array}{l}\text { in presence of } \\
\text { GalN and 6-azauridine } \\
\text { or PALA }\end{array}$ & [45] \\
\hline & AS-30D hepatoma & $\begin{array}{l}\text { FUDP-HexNAc+ more } \\
\text { than FUDP-Hex }+\end{array}$ & & $\begin{array}{l}\text { FUDP sugars } \\
\text { substrates for enzymes } \\
\text { of UDP sugar } \\
\text { metabolism }\end{array}$ & & [49] \\
\hline & $\begin{array}{l}\text { TA3 mamma } \\
\text { carcinoma }\end{array}$ & $\begin{array}{l}\text { FUDP-HexNAc } \\
(6-58 \%)\end{array}$ & & & $\begin{array}{l}\text { percentage dependent } \\
\text { on addition of GlcN } \\
\text { and/or 6-azauridine }\end{array}$ & [46] \\
\hline FUdR & lymphoblast & $\begin{array}{l}\text { dUTP+, dUDP- } \\
\text { GlcNAc+, FdUDP- } \\
\text { GlcNAc+ }\end{array}$ & & & & [50] \\
\hline FUDP-sugars & $\begin{array}{l}\text { chick embryo } \\
\text { microsomes }\end{array}$ & & & $\begin{array}{l}\text { Glc-P-Dol formation } \\
\text { same } K_{\mathrm{m}} \text { and } V_{\mathrm{m}} \text { for } \\
\text { FUDP-Glc and UDP- } \\
\text { Glc } \\
\text { (GlcNAc) })_{2} \text {-PP-Dol } \\
\text { formation } 2 K_{\mathrm{m}} \text { and } \\
\frac{1}{3} V_{\mathrm{m}} \\
\text { for FUDP-GlcNAc } \\
\text { compared to UDP- } \\
\text { GlcNAc }\end{array}$ & & [69] \\
\hline
\end{tabular}

^Figures in parentheses are percentages of total fluoro-nucleotides formed. FUDP, 5-fluoro-UDP; Dol, dolichol; GlcN, glucosamine; GalN, galactosamine; Hex, hexoses; HexNAc, N-acetyl-hexoseamines. See for other abbreviations Table 1 and Fig. 1.

$\uparrow$ increased; $\downarrow$ decreased; = not changed; + formed; - not detectable. 
5FU-nucleotide sugars. The cytotoxic effect of the combination PALA and FUR against rat hepatoma could be increased by Dgalactosamine [47], which is also able to decrease UTP pools and to inhibit glycosylation. Another inhibitor of glycosylation, D-glucosamine [32-34], enhanced the cytotoxicity of 6-azauridine and 5FU against TA3 mammary tumor cells [46]. The addition of amino sugars induced a further depletion of the UTP pool, respectively, by formation and trapping of normally not occurring (F)UDP-galactosamine, and by a very large increase in the concentration of (F)UDP- $N$-acetylglucosamine and (F)UDP- $N$-acetylgalactosamine. The pools of other uridine nucleotide sugars were strongly decreased. In both studies it was postulated that the marked increase in 5-fluoro derivatives of the UDP- $N$-acetylhexosamines was related to the cytotoxic effects of 5FU. Co-incubation with other sugar analogs, Dgalactosone [51] or D-glucosone [52], also resulted in trapping of uridine nucleotide sugar pools and increased incorporation of $5 \mathrm{FU}$.

In addition to depletion, the concentration of uridine nucleotides can also be increased experimentally. In cancer chemotherapy, this is used to reverse cytotoxic effects of antimetabolites such as PALA [53] and 5FU [54-57], both in experimental systems [54, 55, 57] and patients [56]. Uridine is able to increase the UDP-glucose concentration in various tissues, including brain [58], and in cell culture [59]. It was shown that both in tumors and normal tissues uridine increased the pyrimidine nucleotide levels greatly [60]. For isolated rat hepatocytes, we could show that uridine also increased the levels of nucleotide sugars (Pels Rijcken WR, Peters GJ, Ferwerda W, unpublished results). On the other hand, in HT-29 cells uridine at $0.1 \mathrm{mM}$ did not reverse the cytotoxic effects of D-glucosamine [59] (which involves depletion of the UTP pool via formation of UDP- $N$ acetylhexosamines with a concomitant inhibition or aberrant glycosylation of glycoproteins [32-34]). In rat C6 glioma cells the cytotoxic effect of $20 \mathrm{mM}$ glucosamine was even enhanced by $2 \mathrm{mM}$ uridine [61]. This supports to the idea that changes in nucleotide sugar pools in itself can be responsible for the cytotoxic effects.

One study has been directed to the effects of antimetabolites which deplete CTP pools [62] and therefore might influence the formation of CMP-sialic acid. Indeed, in HL-60 cells the depletion of CTP by acivicin could be correlated with inhibition of the sialylation of cell surface glycoconjugates. Inhibition of sialylation was also exhibited by $\mathrm{AraC}$ and hydroxyurea. The effects of the antimetabolites on sialylation could be (partially) restored by the addition of cytidine to the culture media.

MTX can induce the formation of dUDP- $N$-acetylglucosamine [50]. Another deoxynucleotide sugar, dTDP- $N$-acetylglucosamine, could be synthesized in a cell-free system, but not in experiments in vivo [63]. No studies have appeared describing deoxynucleotide sugars as substrates in the glycosylation reactions.

(ii) Effects of purine antimetabolites. Purine antimetabolites mainly interfere with nucleotide sugar metabolism by depletion of guanine nucleotides. Inhibition of IMP-dehydrogenase by e.g. tiazofurin and mycophenolic acid leads to a reduction of GTP [64]. In sarcoma 180 cells these antimetabolites decreased the cellular concentration of both GDP-mannose and GDPfucose, but exhibited no effect on e.g. UDP- $N$-acetylglucosamine. In the same cell system a decrease in the GDP-fucose pool was induced by 6-thioguanine in vitro but also in vivo after injection of the antimetabolite into the host animal [65].
Changes in cellular GDP-sugar concentrations have also been reported upon treatment of HL-60 cells with 6-thioguanine, tiazofurin and mycophenolic acid [66-68]. However, using a variant HL-60 cell line, deficient in hypoxanthine-guanine phosphoribosyl transferase, Sartorelli and co-workers showed that the depletion of guanine nucleotides induced by purine antimetabolites resulted in differentiation rather than direct cell death [66]. Moreover, they could show that the concomitant decrease in GDP-sugar concentration was related also to the differentiation process.

\section{B. Effects of antimetabolites on glycosylation}

(i) Effects on glycosyltransferases. Only a few studies describe a direct effect of FUDP-sugars on metabolic routes involved in the glycosylation process. FUDP-glucose, FUDP-galactose and FUDP- $N$-acetylglucosamine have been tested in vitro as substrates for glycosyltransferases in the glycosylation of glycoconjugates and for enzymes of the nucleotide sugar metabolism. Decreased product formation, in terms of $V_{\max }$, was reported for several FUDP-sugars [49, 69]. Thus, FUDP- $N$-acetylglucosamine and FUDP-glucose were less efficient substrates than the natural UDP-sugars in the formation of lipid-linked precursors for the oligosaccharide chains of glycoproteins in in vitro studies with crude microsomal fractions of primary chick embryo cells [69]. A 50\% reduction in product formation was observed with FUDP- $N$-acetylglucosamine as substrate instead of the natural UDP-sugar. The $K_{\mathrm{m}}$ for the enzyme was decreased, indicating that the FUDP-sugar exhibited a higher affinity than UDP- $N$-acetylglucosamine for the enzyme.

Direct inhibition of glycosyltransferases by $5 \mathrm{FU}$ does not seem likely to occur, since for galactosyltransferase inhibition was observed only in the millimolar concentrations range of $5 \mathrm{FU}$ [70]. In patients, peak levels in plasma are usually not higher than $0.5 \mathrm{mM}$ [71], and decrease within a few hours to below the micromolar level. Furthermore, in colon tumors and healthy mucosa from $5 \mathrm{FU}$ treated patients the level of $5 \mathrm{FU}$ is not higher than $10 \mu M$ [72]. Direct effects on glycosyltransferases by other antimetabolites, however, can occur since a competitive inhibition of serum sialyltransferase has been reported for $\mathrm{AraC}$ $[73,74]$.

(ii) Effects on cell membrane glycoconjugates. In some studies regarding the antimetabolite-induced changes in nucleotide sugar concentrations, accompanying alterations in the binding of lectins to cell-surface glycoproteins have been observed [62, 64, 75-77]. Thus decreased binding of Concanavalin A, specific for mannose-containing oligosaccharide structures, was observed in HL-60 and sarcoma 180 cells after treatment with guanine antimetabolites. Furthermore, different binding characteristics were observed for peanut and soybean agglutinins, lectins specific for exposed galactose and/or $N$-acetylgalactosamine residues, after incubation of desialylated HL-60 cells with AraC, 3-deazauridine, acivicin and hydroxyurea [62].

Both pyrimidine and purine antimetabolites have been reported to induce changes in the metabolic incorporation of radioactive sugars into cellular glycoproteins. In sarcoma 180 cells tiazofurin and mycophenolic acid inhibited the incorporation of both radioactive mannose and fucose into lipid-linked oligosaccharide precursors of cellular glycoproteins, which was accompanied by a decrease in binding of Concanavalin A to the cell surface [64]. Comparable alterations in membrane glycoprotein composition were observed when sarcoma 180 cells 
Table 3. Summary of literature on effects of other antimetabolites on glycosylation

\begin{tabular}{|c|c|c|c|c|c|c|c|}
\hline Antimetabolite & Cell type & $\begin{array}{l}\text { Nucleotide } \\
\text { pools }\end{array}$ & $\begin{array}{l}\text { Metabolic } \\
\text { incorporation }\end{array}$ & $\begin{array}{l}\text { Lectin } \\
\text { binding }\end{array}$ & Miscellaneous & Combination & Ref. \\
\hline \multirow[t]{2}{*}{$6 \mathrm{MMPR}$} & sarcoma 180 & $\mathrm{GTP} \downarrow, \mathrm{UTP} \uparrow$ & $\begin{array}{l}{\left[{ }^{3} \mathrm{H}\right] \mathrm{Man} \downarrow} \\
{\left[{ }^{3} \mathrm{H}\right] \mathrm{GlcN}=}\end{array}$ & Con $\mathrm{A} \downarrow$ & & $\begin{array}{l}\text { adenine counteracts } \\
\text { guanosine enhances } \\
\text { effects }\end{array}$ & [76] \\
\hline & HL-60 leukemia & GTP $\downarrow$ & {$\left[{ }^{3} \mathrm{H}\right] \mathrm{Man} \downarrow$} & & differentiation & adenine counteracts & {$[81]$} \\
\hline $6 \mathrm{MP}$ & L1210 leukemia & & $\begin{array}{l}{\left[{ }^{3} \mathrm{H}\right] \mathrm{Fuc} \uparrow,} \\
{\left[{ }^{3} \mathrm{H}\right] \mathrm{GlcN}=,} \\
{\left[{ }^{3} \mathrm{H}\right] \mathrm{Man}=} \\
{\left[{ }^{3} \mathrm{H}\right] \mathrm{Gal}=}\end{array}$ & & & & [78] \\
\hline \multirow[t]{3}{*}{$6 \mathrm{TG}$} & $\begin{array}{l}\text { sarcoma } 180 \\
\text { 6TG resistant }\end{array}$ & GDP-Fuc $\downarrow$ & $\begin{array}{l}{\left[{ }^{3} \mathrm{H}\right] \text { Fuc } \downarrow,} \\
{\left[{ }^{3} \mathrm{H}\right] \mathrm{GlcN}=} \\
{\left[{ }^{3} \mathrm{H}\right] \mathrm{Fuc}=}\end{array}$ & & & & {$[65]$} \\
\hline & sarcoma 180 & & {$\left[{ }^{3} \mathrm{H}\right] \mathrm{Man} \downarrow$} & $\begin{array}{l}\text { Con } A \downarrow \\
W G A=, R C A=\end{array}$ & & & [75] \\
\hline & L1210 leukemia & & $\begin{array}{l}{\left[{ }^{3} \mathrm{H}\right] \mathrm{Fuc}=,} \\
{\left[{ }^{3} \mathrm{H}\right] \mathrm{GlcN}=,} \\
{\left[{ }^{3} \mathrm{H}\right] \mathrm{Gal}=,} \\
{\left[{ }^{3} \mathrm{H}\right] \mathrm{Man}=}\end{array}$ & & & & {$[78]$} \\
\hline MTX & lymphoblast & $\begin{array}{l}\text { UTP }=\text {, UDP- } \\
\text { GlcNAc }=\text {, dUTP }+ \text {, } \\
\text { dUDP-GlcNAc }+\end{array}$ & & & & & {$[50]$} \\
\hline Aral & WI38 fibroblast & & {$\left[{ }^{14} \mathrm{C}\right] \mathrm{SA} \downarrow$} & & $\begin{array}{l}\text { sialyltransferase } \\
\text { CMP-SA } \\
\text { synthetase } \downarrow \\
\text { CMP-SA, } \\
\text { hydrolase } \downarrow\end{array}$ & & {$[74]$} \\
\hline${ }^{*}$ & HL-60 leukemia & $\mathrm{CTP} \uparrow$ & $\begin{array}{l}\text { de novo synthesis } \\
\text { SA } \downarrow \text { and } \\
\text { resialylation } \downarrow\end{array}$ & $\mathrm{SBA} \uparrow, \mathrm{PNA} \uparrow$ & & & {$[62]$} \\
\hline \multirow[t]{2}{*}{ Ara-CTP } & serum & & & & $\begin{array}{l}\text { sialyltransferase } \\
\downarrow\end{array}$ & & {$[73]$} \\
\hline & WI38 fibroblast & & {$\left[{ }^{14} \mathrm{C}\right] \mathrm{SA} \downarrow$} & & $\begin{array}{l}\text { same effects as } \\
\text { AraC }\end{array}$ & & [74] \\
\hline \multirow[t]{2}{*}{ 3-Deazauridine } & HL-60 leukemia & CTP & de novo & $\mathrm{PNA} \uparrow$ & & & {$[62]$} \\
\hline & L1210 leukemia & UDP-Hex $\uparrow$ & $\begin{array}{l}\text { synthesis } \mathrm{SA}= \\
\text { and } \\
\text { resialylation } \downarrow\end{array}$ & & & & {$[90]$} \\
\hline \multirow[t]{2}{*}{ Pyrazofurin } & L1210 leukemia & UDP-Hex $\downarrow$ & & & & & [90] \\
\hline & $\begin{array}{l}\text { colon tumor } \\
\text { colon, spleen }\end{array}$ & $\begin{array}{l}\mathrm{UTP} \downarrow, \text { CTP } \downarrow \\
\mathrm{UTP}=, \mathrm{CTP}=\end{array}$ & & & & & {$[40]$} \\
\hline \multirow[t]{2}{*}{$\begin{array}{l}\text { Tiazofurin/ } \\
\text { mycophenolic } \\
\text { acid }\end{array}$} & sarcoma 180 & $\begin{array}{l}\text { GDP-Man } \downarrow \text {, GDP- } \\
\text { Fuc } \downarrow \text {, UDP- } \\
\text { GlcNAc }=\end{array}$ & $\begin{array}{l}{\left[{ }^{3} \mathrm{H}\right] \text { Man } \downarrow,} \\
{\left[{ }^{3} \mathrm{H}\right] \text { Fuc } \downarrow} \\
{\left[{ }^{3} \mathrm{H}\right] \mathrm{GlcN}=}\end{array}$ & Con $\mathrm{A} \downarrow$ & & & {$[64]$} \\
\hline & HL-60 leukemia & & $\begin{array}{l}{\left[{ }^{3} \mathrm{H}\right] \mathrm{Man} \downarrow} \\
{\left[{ }^{3} \mathrm{H}\right] \mathrm{GlcN} \downarrow}\end{array}$ & $\mathrm{SBA} \uparrow, \mathrm{PNA} \uparrow$ & differentiation & & {$[68]$} \\
\hline Acivicin & HL-60 leukemia & CTP $\downarrow$ & $\begin{array}{l}\text { de novo } \\
\text { synthesis SA } \downarrow \\
\text { and } \\
\text { resialylation } \downarrow\end{array}$ & $\mathrm{SBA} \uparrow, \mathrm{PNA} \uparrow$ & & & {$[62]$} \\
\hline Hydroxyurea & HL-60 leukemia & $\mathrm{CTP} \uparrow$ & $\begin{array}{l}\text { de novo } \\
\text { synthesis } \\
\text { SA } \downarrow \text { and } \\
\text { resialylation }\end{array}$ & $\mathrm{SBA} \uparrow, \mathrm{PNA} \uparrow$ & & & {$[62]$} \\
\hline
\end{tabular}

$\uparrow$ increased; $\downarrow$ decreased; = not changed; + formed; - not detectable. Con A, Concanavalin A; WGA, wheat germ agglutinin; RCA, Ricinus communis agglutinin; SBA, soy bean agglutinin; PNA, peanut agglutinin. See for other abbreviations Tables 1 and 2 and Fig. 1. 
were incubated with other purine analogs, 6-thioguanine [65, 75] and 6-methylmercaptopurine riboside [76].

We have studied the effect of various pyrimidine and purine antimetabolites on the incorporation of four radioactive sugar precursors into the cellular glycoconjugates of leukemic mouse L1210 cells, using growth-limiting but non-lethal concentrations of the antimetabolites [78] ( $c f$. Tables 2 and 3). 5FU induced an increase in the incorporation of $\left[{ }^{3} \mathrm{H}\right]$ glucosamine, $\left[{ }^{3} \mathrm{H}\right]$ galactose, $\left[{ }^{3} \mathrm{H}\right]$ fucose, and $\left[{ }^{3} \mathrm{H}\right]$ mannose. Mercaptopurine, had no effect on the $\left[{ }^{3} \mathrm{H}\right]$ glucosamine $\left[{ }^{3} \mathrm{H}\right]$ mannose and $\left[{ }^{3} \mathrm{H}\right]$ galactose incorporation, but increased the incorporation of $\left[{ }^{3} \mathrm{H}\right]$ fucose. Another purine analog, 6-thioguanine, did not have a significant effect at all. The effects of 5FU and mercaptopurine on the relative incorporation of the radioactive sugars most likely reflects changes in oligosaccharide structures. This conclusion was based on our finding that the changes in incorporation of the various radioactive sugars in the oligosaccharides was not a result of changes in the specific radioactivity of the corresponding nucleotide-sugar pools in the L1210 cells [78]. In an earlier study Kessel [37] also reported that 5FU induced an increase in the incorporation of $\left[{ }^{3} \mathrm{H}\right]$ glucosamine into $\mathrm{L} 1210$ cells, but a decrease in the $\left[{ }^{3} \mathrm{H}\right]$ fucose incorporation. This discrepancy compared with our result most probably can be explained by the limiting amount of glucose in the culture medium used in his study, which is known to affect the incorporation of sugars too $[79,80]$.

\section{Relationship between antimetabolite-induced changes in glyco- sylation and differentiation or recruitment of cells}

Krug et al. [59] have postulated that changes in nucleotide sugar metabolism have a causal relation with the onset of differentiation or growth inhibition of HT-29 cells. They reported that the induction of differentiation of these cells by glucosamine could not be prevented by restoring the glucosamine-depleted UTP level of the cells to normal values by adding uridine or cytidine, and, most importantly, that the glucosamineinduced change in the UDP- $N$-acetylglucosamine pool was not reduced. Furthermore, Sartorelli and co-workers have shown that, in HL-60 cells, purine antimetabolites not only deplete guanine nucleotides but are also able to induce differentiation $[66,68,81]$. Preceding differentiation, changes in nucleotide sugar levels and a marked reduction of incorporation of $\left[{ }^{3} \mathrm{H}\right] \mathrm{man}$ nose into glycoproteins and lipid-linked oligosaccharide precursors of glycoproteins occur. Changes in glycosylation of cellular and secreted glycoproteins have been reported to coincide with differentiation $[23,24,26,82-86]$. It must be considered, therefore, that some of the antimetabolite-induced changes in glycosylation discussed in this article are a reflection of the onset of maturation of cells.

AraC and MTX have been reported to induce recruitment of quiescent tumor cells to the proliferative state [87-89]. Since it is assumed that the glycosylation changes during the cell cycle [91], it might be possible that the changes in glycosylation of the cells after exposure to these antimetabolites reflect a change in the distribution of the cells over the various phases of the cell cycle. Since AraC has been reported to be a competitive inhibitor for sialyltransferase $[73,74]$ the causal relationship between the AraC-induced change in glycosylation and recruitment and visa vers $a$ has to be further investigated.

\section{CONCLUDING REMARKS}

From the above-mentioned data it is clear that a wide range of antimetabolites - at low doses-are able to induce changes in the glycosylation of glycoproteins. It is generally assumed that antimetabolites exert their cytotoxicity via their interference with RNA and/or DNA synthesis. Changes in glycosylation induced by antimetabolites might be an additional mechanism to cytotoxicity. It is of interest, therefore, to study the effects of antimetabolites on glycosylation not only of tumor cells but also of normal tissues, especially mucosal cells from the intestinal tract and bone marrow cells.

1. Chabner BA. Pyrimidine antagonists. In: Chabner BA, ed. Pharmacologic Principles of Cancer Treatment. Philadelphia, Saunders, 1982.

2. Jolivet J, Cowan KH, Curt GA, Clendeninn NJ, Chabner BA. The pharmacology and clinical use of methotrexate. New Engl $\mathcal{F} \mathrm{Med}$ 1983, 309, 1094-1104.

3. Glover AB, Leyland-Jones B. Biochemistry of azacitidine: a review. Cancer Treat Rep 1987, 71, 959-964.

4. Martin DS. Biochemical modulation: perspective and objectives. In: Harrap KR, Conners TA, eds. Proceedings of the Eighth BristolMyers Symposium on Cancer Research: New Avenues in Developmental Cancer Chemotherapy. New York, Academic Press, 1987, 113-162.

5. Pinedo HM, Peters GJ. Fluorouracil: biochemistry and pharmacology. F Clin Oncol 1988,6, 1653-1664.

6. Feizi T, Childs RA. Carbohydrates as antigenic determinants of glycoproteins. Biochem. F 1987, 245, 1-11.

7. Olden K, Parent JB, White SL. Carbohydrate moieties of glycoproteins. A re-evaluation of their function. Biochim Biophys Acta 1982, 650, 209-232.

8. Loomes LM, Uemura K-I, Childs RA et al. Erythrocyte receptors for mycoplasma pneumoniae are sialylated oligosaccharides of Ii antigen type. Nature 1984, 307, 560-563.

9. Goudemand J, Mazurier C, Samor B, Bouquelet S, Montreuil J, Goudemand M. Effect of carbohydrate modifications of factor VII I/von Willebrand factor on binding of platelets. Thrombosis Haemostasis 1985, 53, 390-395

10. West CM. Current ideas on the significance of protein glycosylation. Mol Cell Biochem 1986, 72, 3-20.

11. Warren L, Buck CA, Tuszynski GP. Glycopeptide changes and malignant transformation. A possible role for carbohydrate in malignant behaviour. Biochem Biophys Acta 1978, 516, 97-117.

12. Smets LA, Van Beek W. Carbohydrates of the tumor cell surface. Biochim Biophys Acta 1980, 738, 237-249.

13. Kobata A, Yamashita K. The sugar chains of $\gamma$-glutamyltranspeptidase. Pure Appl Chem 1984, 56, 821-823.

14. Yamashita K, Tachibana Y, Ohkura T, Kobata A. Enzymatic basis for the structural changes of asparagine-linked sugar chains of membrane glycoproteins of baby hamster kidney cells induced by polyoma transformation. F Biol Chem 1985, 260, 3963-3969.

15. Narasimhan S, Schachter H, Rajalakshmi S. Expression of $N$ acetylglucosaminyltransferase III in hepatic modules during rat liver carcinogenesis promoted by orotic acid. 7 Biol Chem 1988, 263, 1273-1281.

16. Dennis JW, Laferte S, Fukuda M, Dell A, Carver JP. Asn-linked oligosaccharides in lectin-resistant tumor-cell mutants with varying metastatic potential. Eur F Biochem 1986, 161, 359-373.

17. Van Beek W, Tulp A, Bolscher J, Blanken G, Roozendaal K, Egbers M. Transient versus permanent expression of cancer-related glycoproteins on normal versus leukemia myeloid cells coinciding with marrow egress. Blood 1984, 63, 170-176.

18. Fukuda M, Bothner B, Ramsamooj P et al. Structures of sialylated fucosyl polylactosaminoglycans isolated from chronic myelogenous leukemia cells. F Biol Chem 1985, 260, 12957-12967.

19. Nicolson GL. Cell surface molecules and tumor metastatis. Regulation of metastatic phenotypic diversity. Exptl Cell Res 1984, 150, 3-22.

20. Bolscher JGM, Schallier DCC, Van Rooy H, Storme GA, Smets LA. Modification of cell surface carbohydrates and invasive behaviour by an alkyl-lysophospholid. Cancer Res 1988, 48, 977-982.

21. Dennis JW, Laferte S, Waghorne C, Breitman ML, Kerbel BS. $\beta 1 \rightarrow 6$ branching of Asn-linked oligosaccharides is directly associated with metastatis. Science 1987, 236, 582-585.

22. Hakomori S. Glycosphingolipids. Ann Rev Immunol 1984, 2, 103-126. 
23. Koenderman AHL, Wijermans PW, Van den Eijnden DH. Changes in the expression of $\mathrm{N}$-acetylglucosaminyltransferase III, IV and V associated with the differentiation of HL-60 cells. FEBS Lett 1987 , $22,42-46$.

24. De Heij HT, Kloosterman M, Koppen PL, Van Boom JH, Van den Eijnden DH. Specific expression of a myeloid-associated CMP. NeuAc:Gal $\beta 1 \rightarrow 3$ GalNAc-R $\alpha 2 \rightarrow 3$-sialyltransferase and the sialyl$\mathrm{X}$ determinant in myeloid human-mouse cell hybrids containing human chromosome 11. Cancer Res 1988, 48, 1489-1493.

25. Paulson JC, Colley KJ. Glycosyltransferases: structure, localization, and control of cell-type-specific glycosylation. 7 Biol Chem 1989, 264, 17615-17618.

26. Howard D, Fukuda M, Fukuda MN, Stanley P. The GDP-Fuc: $N$ acetylglucosaminide $3-\alpha-\mathrm{L}$-fucosyltransferase of LEC11 and LEC12 Chinese hamster ovary mutants exhibit novel specificities for glycolipid substrates. F Biol Chem 1987, 262, 16830-16837.

27. Kornfeld R, Kornfeld S. Assembly of asparagine-linked oligosaccharides. Ann Rev Biochem 1985, 54, 631-664.

28. Schachter H. Biosynthetic controls that determine the branching and microheterogeneity of protein-bound oligosaccharides. Biochem Cell Biol 1986, 64, 163-181.

29. Carraway KL, Hull SR. O-Glycosylation pathway for mucin-type glycoproteins. BioEssays 1989, 10, 117-121.

30. Basu S, Basu M. Expression of glycosphingolipid glycosyltransferase in development and transformation. In: Horowitz MI, ed. The Glycoconjugates. New York, Academic Press, 1982, Vol. 3, 265-285.

31. Hirschberg CB, Snider MD. Topography of glycosylation in the rough endoplasmic reticulum and Golgi apparatus. Ann Rev Biochem 1987, 56, 63-87.

32. Koch HU, Schwarz RT, Scholtissek C. Glucosamine itself mediates reversible inhibition of protein glycosylation. A study of glucosamine metabolism at inhibitory concentrations in influenza-virusinfected cells. Eur F Biochem 1979, 94, 515-522.

33. Morin MJ, Porter CW, McKernan P, Bernacki RJ. The biochemical and ultrastructural effects of tunicamycin and D-glucosamine in L1210 leukemic cells. F Cell Physiol 1983, 114, 162-172.

34. Stewart JR, Kenny AJ. Proteins of the kidney microvillar membrane. Effect of monensin, vinblastine, swainsonine and glucosamine on the processing and assembly of endopeptidase-24.11 and dipeptidyl peptidase IV in pig kidney slices. Biochem 7 1984, 224, 559-568

35. Monnet D, Durand D, Biou D, Feger J, Durand G. D-Galactosamine-induced liver injury: a rat model to study the heterogeneity of the oligosaccharide chains of $\alpha_{1}$-acid glycoprotein. 7 Clin Chem Clin Biochem 1985, 23, 249-253.

36. Stanley P, Chaney W. Control of carbohydrate processing. Mol Cell Biol 1985, 5, 1204-1211.

37. Kessel D. Cell surface alterations associated with exposure of leukemia L1210 cells to fluorouracil. Cancer Res 1980,40, 322-324.

38. Tomasz A, Borek E. The mechanism of bacterial fragility produced by 5-fluorouracil: the accumulation of cell wall precursors. Proc Natl Acad Sci USA 1960, 46, 324-327.

39. Pogolotti AL, Nolan PA, Santi PV. Methods for the complete analysis of 5-fluorouracil metabolites in cell extracts. Anal Biochem $1981,117,178-186$.

40. Brockman RW, Chaddix SC, Rose LM. Biochemical aspects of chemotherapy of mouse colon carcinoma. Cancer 1977, 40, 2681-2691

41. Iigo M, Kuretani K, Hoshi A. Relationship between antitumor effect and metabolites of 5 -fluorouracil in combination treatment with 5-fluorouracil and guanosine in ascites sarcoma 180 tumor system. Cancer Res 1983, 43, 5687-5694.

42. Peters GJ, Laurensse E, Lankelma J, Leyva A, Pinedo HM Separation of several 5 -fluorouracil metabolites in various melanoma cell lines. Evidence for the synthesis of 5-flourouracil-nucleotide sugars. Eur 7 Cancer Clin Oncol 1984, 20, 1425-1431

43. Parker WB, Klubes P. Enhancement by uridine of the anabolism of 5-fluorouracil in mouse T-lymphoma (S-49) cells. Cancer Res $1985,45,4249-4256$

44. Day JL, Sadee W. Determination of 5-fluorouridine diphosphate glucose as a metabolite of 5 -fluorouracil in mouse T-lymphoma (S-49) cells using high-performance liquid chromatography. 7 Chromatogr 1986, 356, 445-449.

45. Holstege A, Herrmann B, Keppler DOR. Increased formation of nucleotide derivatives of 5 -fluorouridine in hepatoma cells treated with inhibitors of pyrimidine synthesis and D-galactosamine. FEBS Lett 1978, 95, 361-365.
46. Holstege A, Keppler D. Effects of D-glucosamine and 6-azauridine on nucleotide contents, 5-fluorouridine uptake, and cytotoxicity in TA3 mammary tumor cells. 7 Natl Cancer Inst 1986, 76, 485-492.

47. Anukarahanonta T, Holstege A, Keppler DOR. Selective enhancement of 5-fluorouridine uptake and action in rat hepatomas in vivo following pretreatment with D-galactosamine and 6-azauridine or $N$-(phosphonacetyl)-L-aspartate. Eurf Cancer 1980, 10, 1171-1180.

48. Pels Rijcken WR, Telleman F, Peters GJ, Ferwerda W. Incorporation of 5-fluorouracil into nucleotide sugars and the effect on glycoconjugates in rat hepatoma cells and hepatocytes. Adv Exp Med Biol 1989, 253B, in press.

49. Weckbecker G, Keppler DOR. Substrate properties of 5-fluorouridine diphosphosugars detected in hepatoma cells. Biochem Pharmacol 1984, 33, 2291-2298.

50. Peterson MS, Ingraham HA, Goulian M. 2'-Deoxyribosyl analogues of UDP- $N$-acetylglucosamine in cells treated with methotrexate or 5-fluorodeoxyuridine. F Biol Chem 1983, 258, 10831-10834.

51. Keppler DOR, Schulz-Holstege C, Fauler J, Reiffen KA, Schneider $\mathrm{F}$. Inhibition of $\mathrm{L}$-fucose incorporation into glycoprotein of sarcoma 180 ascites cells by 6-thioguanine. Biochem $\mathcal{F}$ 1982, 206, 139-146.

52. Holstege A, Schulz-Holstege C, Henninger H, Reiffen KA, Schneider F, Keppler DOR. Uridylate trapping induced by the C-2modified D-glucose analogs glucosone, fluoroglucose and glucosamine. Eur F Biochem 1982, 121, 469-474.

53. Moyer JD, Handschumacher RE. Selective inhibition of pyrimidine synthesis and depletion of nucleotide pools by $N$-(phosphonacetyl)L-aspartate.Cancer Res 1979, 39, 3089-3094.

54. Martin DS, Stolfi RL, Sawyer RC, Spiegelman S, Young CW. High-dose 5-fluorouracil with delayed uridine 'rescue' in mice. Cancer Res 1982, 42, 3964-3970.

55. Klubes P, Cerna I, Meldon MA. Uridine rescue from the lethal toxicity of 5-fluorouracil in mice. Cancer Chemother Pharmacol 1982 $8,17-21$.

56. Van Groeningen CJ, Peters GJ, Leyva A, Laurensse EJ, Pinedo HM. Reversal of 5-fluorouracil-induced myelosuppression by prolonged administration of high-dose uridine. 7 Natl Cancer Inst 1989, 81, 157-162.

57. Peters GJ, Van Dijk J, Laurensse E et al. In vitro biochemical and in vivo biological studies of the uridine 'rescue' of 5-fluorouracil. $\mathrm{Br}$ 7 Cancer 1988, 57, 259-265.

58. Popov N, Schmidt S, Matthies H. Protective effect of uridine on D-galactosamine-induced deficiency in brain uridine phosphates. Biomed Biochim Acta 1984, 43, 1399-1404.

59. Krug E, Zweibaum A, Schulz-Holstege C, Keppler D. D-Glucosamine-induced changes in nucleotide metabolism and growth of colon carcinoma cells in culture. Biochem f 1984, 217, 701-708.

60. Peters GJ, Van Groeningen CJ, Laurensse E, Lankelma J, Leyva A, Pinedo HM. Uridine-induced hypothermia in mice and rats in relation to plasma and tissue levels of uridine and its metabolites. Cancer Chemother Pharmacol 1987, 20, 101-108.

61. Calvaruso G, Taibi G, Torregrossa, Romano N, Tesoriere G. Uridine enhances the cytotoxic effect of D-glucosamine in rat C6 glioma cells. Life Sci 1986, 39, 2221-2227.

62. Hindenburg AA, Taub RN, Grant S, Chang G, Baker MA. Effects of pyrimidine antagonists on sialic acid regeneration in HL-60 cells. Cancer Res 1985, 45, 3048-3052.

63. Kornfeld S, Ginsburg V. Thymidine 5'-diphosphate $N$-acetyl-Dglucosamine pyrophosphorylase activity of hog gastric mucosa. Biochem Biophys Res Commun 1964, 17, 578-581.

64. Sokoloski JA, Sartorelli. Effects of the inhibitors of IMP dehydrogenase, tiazofurin and mycophenolic acid on glycoprotein metabolitism. Mol Pharmacol 1985, 28, 567-573.

65. Lazo JS, Hwang KM, Sartorelli AC. Inhibition of L-fucose incorporation into glycoprotein of sarcoma 180 ascites cells by 6 -thioguanine. Cancer Res 1977, 37, 4250-4255.

66. Ishiguro K, Schwarz EL, Sartorelli AC. Characterization of the metabolic forms of 6-thioguanine responsible for cytotoxicity and induction of differentiation of HL-60 acute promyelocytic cells. $\mathcal{F}$ Cell Physiol 1984, 121, 383-390.

67. Lucas DL, Webster HK, Wright DG. Purine metabolism in myeloid precursor cells during maturation. Studies with the HL-60 cell line. $\mathcal{F}$ Clin Invest 1983, 72, 1889-1900.

68. Sokoloski JA, Blair OC, Sartorelli AC. Alterations in glycoprotein synthesis and guanosine triphosphate levels associated with differentiation of HL-60 leukemia cells produced by inhibitors of inosine 5'-phosphate dehydrogenase. Cancer Res 1986, 46, 2314-2319.

69. McDowell W, Weckbecker G, Schwarz RT. Uridine sugar nucleo- 
tides modified in their nucleoside moieties and their effect on lipidlinked saccharide formation in vitro. BioSci Rep 1986, 6, 435-443.

70. Choudhury K, Chaterjee SK, Bhattacharaya M, Barlow JJ. Inhibition of galactosyltransferase by 5 -fluorouracil. Biochem Pharmacol 1982, 31, 459-460.

71. Kok RM, De Jong APJM, Van Groeningen CJ, Peters GJ, Lankelma J. Highly sensitive determination of 5 -fluorouracil in human plasma by capillary gas chromatography and negative ion chemical ionization mass spectrometry. 7 Chromatogr 1985, 343, 59-66.

72. Peters GJ, Lankelma J, Van Groeningen CJ et al. Tissue pharmacodynamics of 5-fluorouracil (5FU) in colorectal cancer of mice and patients. Proc. of the 10th Anniversary Meeting of the EORTC Pharmacokinetics and Metabolism Group, 1988, Abstract P27.

73. Klohs WD, Bernacki RJ, Korytnyk W. Effects of nucleotides and nucleotide analogs on human serum sialyltransferase. Cancer Res 1979, 39, 1231-1238.

74. Myers-Robfogel MW, Spataro AC. 1- $\beta$-D-Arabinofuranosyl cytosine nucleotide inhibition of sialic acid metabolism inWI-38 cells. Cancer Res 1980, 40, 1940-1943.

75. Lazo JS, Chansky CW, Sartorelli AC. Reduction in cell surface concanavalin A binding and mannose incorporation into glycoproteins of sarcoma 180 by 6-thioguanine. Biochem Pharmacol 1979, $28,583-588$

76. Sokoloski JA, Sartorelli AC. Inhibition of mannose incorporation into glycoproteins and dolichol-linked intermediates of sarcoma 180 cells by 6-methylmercaptopurine ribonucleoside. Int 7 Cancer 1987, 39, 764-768.

77. Morin MJ, Porter CW, McKernan P, Bernacki RJ. The biochemical and ultrastructural effects of tunicamycin and D-glucosamine in L1210 leukemic cells. F Cell Physiol 1983, 114, 162-172.

78. De Graaf TW, Slot SS, Peters GJ, Van Dijk W. Changes in Glycosylation of L1210 cells after exposure to various antimetabolites (submitted).

79. Baumann H, Jahreis GP. Glucose starvation leads in rat hepatoma cells to partially $N$-glycosylated proteins including $\alpha_{1}$-acid glycoprotein. Identification by endoglycolytic digestions in polyacrylamide gels. F Biol Chem 1983, 258, 3942-3949.

80. Strube KH, Schott HH, Geyer R. Carbohydrate structure of glycoprotein 52 encoded by the polycythemia-inducing strain of frien spleen focus-forming virus. F Biol Chem 1988, 263, 3763-3771.

81. Sokoloski JA, Sartorelli AC. Inhibition of the synthesis of glycoproteins and induction of the differentiation of HL-60 promyelo- cytic leukemia cells by 6-methylmercaptopurine ribonucleoside. Cancer Res 1987, 47, 6283-6287.

82. Skubitz KM, August JT. Analysis of cell-surface protein changes accompanying differentiation of HL-60 cells. Arch Biochem Biophys 1983, 226, 1-9.

83. Mizoguchi A, Takasaki S, Maeda S, Kobata A. Changes in the asparagine-linked sugar chains of human promyelocytic leukemic cells (HL-60) during monocytoid differentiation. Decrease of highmolecular weight oligosaccharides in acidic fraction. $7 \mathrm{Biol}$ Chem 1984, 259, 11959-11957.

84. Carlsson SR, Sasaki H, Fukuda M. Structural variations of $O$-linked oligosaccharides present in leukosialin isolated from erythroid, myeloid and T-lymphoid cell lines. 7 Biol Chem 1986, 261, 12787-12795.

85. Momoi T, Shinmoto M, Kasuya J, Senoo H, Suzuki Y. Activation of CMP- $N$-acetylneuraminic acid:lactosylceramide sialyltransferase during the differentiation of HL-60 cells induced by $12-O$-tetradecanoylphorbol-13-acetate. F Biol Chem 1986, 261, 16270-16273.

86. Collins SJ. The HL-60-promyelocitic leukemia cell line: proliferation, differentiation, and cellular oncogene expression. $7 \mathrm{Am}$ Soc Hematol 1987, 70, 1233-1245.

87. Smets LA, Taminiau J, Hälen K, De Waal F, Behrendt H. Cell kinetic responses in childhood acute nonlymphocytic leukemia during high-dose therapy with cystosine arabinoside. Blood 1983, 61, 79-84.

88. Lorico A, Rappa G, Boiocchi M, Anzanello F, d'Incalci M. Increase in etoposide-induced topoisomerase II-mediated DNA breaks after cell synchronization induced by low doses of methotrexate. Biochem Pharmacol 1988, 37, 1883-1884.

89. Walter J, Maurer-Schultze B. Tumor cell recruitment in the mouse adenocarcinoma EO 771 directly demonstrated by double labeling with $\left[{ }^{3} \mathrm{H}\right]-$ and $\left[{ }^{14} \mathrm{C}\right]$ thymidine and flow cytometry. 7 Cancer Res Clin Oncol 1989, 115, 53-60.

90. Sant ME, Lyons SD, Kemp AJ, McClure LK, Szabados E, Christopherson RI. Dual effects of pyrazofurin and 3-deazauridine upon pyrimidine and purine biosynthesis in mouse L1210 leukemia. Cancer Res 1989, 49, 2645-2650.

91. Scheideler MA, Lockney MW, Dawson G. Cell-cycle dependence of a ganglioside glycosyltransferase activity and its inhibition by enkephalin in a neurotumor cell line. $\mathcal{F}$ Neurochem 1984, 42, 1175-1182. 